\title{
Demir veya Çelikten Eşya Ticaretinde Türkiye'nin Karşılaştırmalı Üstünlüğü ve Rekabet Gücü
}

\author{
Hüseyin FIDAN ${ }^{1}$ \\ ${ }^{1}$ Graduate Student, KTO Karatay University, Social Sciences Institute, Konya, Turkey
}

Geliş Tarihi/Received: 18.11.2019

Kabul Tarihi/Accepted: 11.12.2019
Doi: doi.org/10.31200/makuubd.648388

Araştırma Makalesi/Research Article

\section{ÖZET}

Demir-Çelik endüstrisi Türkiye ekonomisi için hem dış ticaret açığının kapatılması hem de istihdam bakımından önemli bir paya sahiptir. Türkiye'nin dünya ölçeğinde rekabet gücüne sahip olduğu önemli bir endüstri koludur. Bu çalışmanın amacı, Türkiye demir veya çelikten eşya sektörünün uluslararası ticarette rekabet gücünü analiz etmektir. Bu çalışmada, GTİP 6 ölçeğinde demir veya çelikten eşya grubu incelenmiştir. Çalışmada Balassa'nın Açıklanmış Karşılaştırmalı Üstünlükler (RCA) endeksi ve Vollrath endeksleri kullanılmıştır. Alt sektör bazında rekabet analizi yapılmış ve ihracatçı firmalara yol gösterici sonuçlar elde edilmiştir. 2001-2018 dönemini kapsayan analizlere ait veriler Uluslararası Ticaret Merkezi (ITCTRADEMAP) ve Türkiye İstatistik Kurumu (TÜİK) veri tabanlarından elde edilmiştir. Bu analizler için dünyanın önemli ihracatçı ülkeleri olan Almanya, İtalya, Fransa, Polonya, Çek Cumhuriyeti, Avusturya ve Hollanda incelenmiştir. Elde edilen Balassa ve Vollrath endekslerine göre; Türkiye demir veya çelikten eşya ihracatında uluslararası karşılaştırmalı üstünlüğe sahiptir. Balassa endeksine göre Türkiye, Fransa ve Hollanda'ya karşı rekabet üstünlüğüne sahipken; Vollrath endeksine göre; Türkiye, Almanya, Fransa, Polonya, Çek Cumhuriyeti, Avusturya ve Hollanda karşı rekabet üstünlüğüne sahiptir.

Anahtar kelimeler: Dış Ticaret, Rekabet Gücü, Demir-Çelik Eşya, İhracat. 


\title{
Turkey's Comparative Advantage and Competitive Power in Trade of Articles of Iron or Steel
}

\begin{abstract}
The iron and steel industry has a significant share both in terms of closing foreign trade deficit and the employment. It is an important industry branch in which we have competitiveness on global scale. The purpose of this study is to analyze the Turkey articles of iron or steel sector's competitive power in international trade. In this study, articles of iron or steel were examined on HS 6 scale. In the study, Balassa's Revealed Comparative Advantage (RCA) and Vollrath indexes were used. The articles of iron or steel trade data is obtained from the International Trade Center (ITC-TRADEMAP) and Turkish Statistical Institute (TUIK) databases and calculated for the years between 2001-2018. For this analyses, Germany, Italy, France, Poland, Czech Republic, Austria and Netherlands were taken into account as important exporter countries in the world. According to obtained Balassa's and Vollrath's indexes, Turkey has comparative advantage in the international trade in the articles of iron or steel export. According to Balassa index, while Turkey has comparative advantage against Fransa and Netherlands; according to Vollrath index, Turkey has comparative advantage against Germany, France, Poland, Czech Republic, Austria and Netherlands.
\end{abstract}

Keywords: Foreign Trade, Competitiveness, Articles of Iron or Steel, Export.

\section{GIRİŞ}

Mikro ölçekte firmalar ve endüstriler, makro ölçekte ise ülke ekonomi ve ticaretleri küresel dünya ticaretinde aktif rol alma ve etkin güce sahip olma hedefini taşımaktadırlar. Bunun için küresel pazarda yer almak ve uluslararası arenada kalıcı olmak için pazar paylarını artırmanın yollarını arayarak fırsatları değerlendirip avantaj sağlama amacını taşırlar. Bu makro hedeflere ulaşmanın yolu da firmaların aktif olarak rol almalarına bağlıdır.

Sanayi devriminden sonra birbirine yaklaşan uluslararası ekonomilerde rekabet gücü kavramı önem kazanmıştır. Rekabet gücü, ülkelerin, sektörlerin veya malların dünya ticaretinden aldıkları payı göstermek için uygulanmaktadır.

Ticaret Bakanlığı verilerine göre 2018 yılında Türkiye 83.286 ihracatçı firma tarafindan ihracat yapılarak toplam 167,92 milyar dolarlık gelir elde etmiştir. Bu çalışmada detaylı analizlerine yer vereceğimiz RCA değeri bakımından Türkiye'nin avantaja sahip olduğu 732690 GTIPP numarasına sahip “demir veya çelikten eşya” sektörünün ihracat getirisi 758,40 
milyon dolardır. 2004 yılından itibaren (2007 y1lı istisna) Türkiye bu endüstri dalında uluslararası ticarette Açıklanmış Karşılaştırmalı Üstünlükler (AKÜ) endeksine göre avantaja sahip veriler elde etmiştir.

Bu çalışma, Türkiye'nin demir veya çelikten eşya sektörüne ait verilerini küresel ölçekte değerlendirmek ve ayrıca rekabet halinde olduğumuz Almanya, İtalya, Fransa, Polonya, Çek Cumhuriyeti, Avusturya ve Hollanda ülkelerle karşılaştırarak rekabet gücünü ve karşılaştırmalı üstünlüğünü ortaya koymayı amaçlamaktadır. Dünya ticaretinde en çok ihracat yapan Çin ve ABD karşılaştırmalı analizlere dâhil edilmemiştir. 2001-2018 dönemini kapsayan bu çalışmada, demir veya çelikten eşyalara ait veriler dünya ölçeğinde değerlendirildikten sonra rekabet içerisindeki ülkelerle olan rekabet gücü analiz edilmiştir. Uygulama aşamasında Balassa'nın açıklanmış karşılaştırmalı üstünlükler endeksi ve Vollrath'ın literatüre kazandırmış olduğu endeksler kullanılmıştır. Çalışmanın sonuç kısmında, kaynaklardan elde edilen veriler yorumlanarak hesaplanan analiz sonuçları değerlendirilmiş ve öneriler ifade edilmiştir.

Literatürde Türkiye demir veya çelikten eşyalar için 6 haneli GTİP düzeyinde bir çalışma yapılmamıştır. Çalışmalar genellikle sektörün genel durumunu ortaya koymak amacıyla fasıllar halinde ele alınmıştır. Sektöre ait genel dış ticaret verileri yansıtılmıştır. İlgili çalışmalar genellikle diğer sektör verileri ile birlikte sektör bazında ve dar kapsamlı incelenmiştir. Bu çalışmanın diğer çalışmalardan farkı; Türkiye demir veya çelikten eşyalar endüstrisine ait verilerin Balassa ve Vollrath endekslerinin birlikte kullanılması ile ayrıntılı olarak analize tabi tutulması ve yıllara göre kapsamlı değerlendirilmesidir.

\section{LITERATÜR ARAŞTIRMASI}

Demir-çelik endüstrisi ile ilgili genel kapsamlı çeşitli çalışmalar literatürde mevcuttur. $\mathrm{Bu}$ çalışmalarda alt sektörlerden bahsedilmemiş, bölgesel ölçekte (Avrupa Birliği, BRIC ülkeleri bağlamında) daha dar kapsamlı olarak ele alınmış ve diğer endüstrilerle birlikte değerlendirilmiştir. Bu çalışmalarda genellikle imalat sanayi veya genel dış ticaret verileri esas alınarak Türkiye'nin rekabet gücünü analiz etmeye yönelik analizler yapılmıştır. Örneğin Türkiye İhracatçılar Meclisi'nin 2019 raporunda genel dış ticaret verileri, Türkiye Kalınma Bankası'nın 2006 yılında hazırladı̆̆ı raporda Türkiye'nin imalat sanayi dış ticaret verileri değerlendirilmiştir. $\mathrm{Bu}$ çalışmalara konu edilen rekabet gücü analizleri, açıklanmış karşılaştırmalı üstünlükler teorisine göre Balassa ve Vollrath endeksleri kullanılarak değerlendirmeye tabi tutulmuştur. Bu çalışmaların ortak sonucu olarak; Türkiye, genel imalat sanayinde rekabet dezavantajına sahipken, demir-çelik sanayinde rakiplerine karşı rekabet 


\section{Fidan, $\boldsymbol{H}$.}

avantajına sahip olduğu belirtilmektedir. Demir veya çelikten eşya ürünlerini içeren özel bir çalışma bu analizlere dahil edilmemiştir.

Sarıçoban vd. (2017) tarafından yapılan çalışmada, “Türkiye’nin İmalat Sanayi Ürünleri İhracatındaki Küresel Rekabet Gücünün Belirlenmesi” amacıyla 1996-2015 dönemine ait verileri AKÜ ve Vollrath endekslerini kullanarak analiz etmiştir. Türkiye'nin 157 farklı üretim sanayindeki ürünlerin ihracatından 57 adedinde rekabet avantajına sahipken, aynı üretim grubundaki diğer 100 ürün grubunda rekabet avantajına sahip olmadığı sonucuna varılmıştır.

Manavgat ve Kaya (2016)'ın yaptığı analizde, Türk imalat sanayinin 2003-2012 döneminde en fazla ticaret yaptığı 25 ülke için rekabet gücünü analiz etmiştir. Analiz sonucunda, Türk imalat sanayine ait verilerin, ihracat piyasa payının teknoloji seviyesine göre değiştiği ve fiyat etkenlerinin rekabet gücünde etkili olduğunu gözlemlemiştir.

Yalçınkaya vd. (2009) çalışmalarında, 1989-2009 dönemine ait veriler temelinde Türkiye'nin Gümrük Birliği kapsamında dış ticarette rekabet gücüne etki eden döviz kuru ve ara malı ithalatı değişkenleri ve etkileri üzerinde durmuştur. Sonuç itibariyle, döviz kuru politikalarının ara malı ithalatı ile birleşerek ekonomik kırılganlığa sebep olduğunu ortaya çıkarmıştır.

Şahin (2016)'in çalışmasında, İmalat sanayi rekabet gücü bakımından Türkiye'yi BRIC ülkelerine karşı AKÜ endeksi ile analiz etmiştir. Sonuç itibariyle; Türkiye'nin SITC 6 ve SITC 8 sanayi grubunda rekabet gücünün Brezilya, Rusya ve Hindistan karşısında yüksek ancak Çin karşısında düşük olduğu görülmüştür.

Bağcı (2016) tarafından yapılan çalışmada, 1995-2014 dönemini kapsayan analizinde Türkiye'nin imalat sektörü küresel rekabet gücünü ortaya koymaya çalışmıştır. Türkiye'nin imalat sanayi sektörü genelinde değerlendirme yapıldığında, küresel rekabet gücüne sahip olmadığı; tekstil, demir veya çelik, giyim, yiyecek ve içecek ile otomotiv ürünleri sektöründe rekabet gücüne sahip olduğu tespit edilmiştir

Türkiye İhracatçılar Meclisi (2019) tarafından yayınlan raporda Türkiye'nin 2018 yılına ait dış ticaret verilerinin analizi yapılmıştır. Rekabet gücü analizleri için Balassa'nın RCA endeksinden yararlanılmıştır. Türkiye'nin uluslararası rekabet gücünün olduğu ürünlerin tespiti yapılmış ve potansiyel hedef Pazar belirleme hususunda ihracatçılara yol haritası sunulmuştur. RCA değeri 1'den büyük 47 (demir veya çelikten eşya dâhil) ürün tespit edilmiştir. Bu ürünlerin 
en büyük ithalatçıları arasında $\mathrm{AB}$ ülkelerinin yer aldığı ve Polonya, Meksika ve Çek Cumhuriyeti gibi ülkelerin hedef pazar olduğu belirtilmiştir.

Türkiye Kalkınma Bankası A.Ş.'nin 2006 yılında yayınlanan raporunda dış ticarete ilişkin rekabet gücü analizinde sanayi sektörü değerlendirilmiştir. İlgili bu çalışmada, Balassa ve Vollrath endeksleri dikkate alınarak 1995-2005 dönemine ait veriler sektörler bazında analiz edilmiştir. Amaç olarak, elde edilen verilerle mevcut durum ile birlikte kapsamlı olarak sektörün geleceği planlanmaya çalışılmıştır. Çalışmadan çıkartılan sonuca göre; uluslararası ticarette genel itibariyle rekabet gücü zayıf malların olduğu ve söz konusu bu ürünlerin rekabet gücünün pozitif yönlü artış eğiliminde olduğu belirlenmiştir.

Özdamar (2014), çalışmasında imalat sanayinin çeşitli teknoloji seviyeleri açısından Türkiye'nin 28 Avrupa Birliği ülkesi ile ticaretinin yapısı ve bu ülkeler karşısındaki rekabet gücü, Gümrük Birliği anlaşmasından sonraki 1996 ile 2012 yılları arasındaki verileri incelemiştir. RCA endeks sonuçlarına göre, Türkiye ileri ve orta-ileri sanayiler düzeyinde AB karşısında dezavantaj durumunda iken, orta-düşük ve düşük sanayiler düzeyinde rekabet avantajına sahiptir.

Çeştepe ve Tunçel (2018) yaptıkları çalışmada Türkiye'nin demir çelik endüstrisine ait uluslararası rekabet gücü analizinde açıklanmış karşılaştırmalı üstünlükler yöntemi kullanılarak uluslararası rekabet gücünü belirlemeye çalışmışlardır. Çalışmada, Türkiye'nin demir çelik sektöründe uluslararası ticaretteki rekabet gücü 2007-2016 dönemine ait veriler esas alınarak incelenmiştir. Analiz sonuçları dikkate alındığında, Türkiye'nin demir çelik endüstrisinde, grup olarak yassı mamullerde düşük rekabet gücüne sahipken, yine grup bazında uzun mamullerde ise yüksek rekabet gücüne sahip olduğu sonucuna varılmıştır.

\section{MATERYAL VE YÖNTEM}

Demir veya çelikten eşya sektöründe Türkiye'nin dünya ölçeğinde rekabet gücünü tespit edebilmek amacıyla kullanılan makro veriler bu analiz çalışmamızın esasını oluşturmaktadır. Analizlerimize temel teşkil eden diş ticaret verileri 2001-2018 dönemine ait verilerdir. Veriler ikincil kaynaklardan alınarak tasnif edilmiştir. Söz konusu veriler, güvenilir ve güncel veri sağlama kaynağı olarak kabul edilen Uluslararası Ticaret Merkezi'nin (ITC) istatistiki veri tabanı olan "Trademap" (Çelik vd., 2019: 42) ve Türkiye İstatistik Kurumu (TÜİK) üzerinden elde edilmiştir. 


\section{Fidan, $\boldsymbol{H}$.}

Bu çalışmada resmi adı Armonize Mal Tanımı ve Kodlama Sistemi (The Harmonized Commodity Description and Coding Systems) olan ve Türkiye literatüründe Gümrük Tarife İstatistik Pozisyon numarası (GTIP) olarak bilinen uluslararası ticarete konu olan bütün ürünler için kullanılan milletlerarası ticari sınıflama sistemi uygulanmıştır (Türkiye Odalar ve Borsalar Birliği [TOBB], 2015: 6). Çalışmamıza konu olan demir veya çelikten eşya için HS 6 haneli “732690” koduna göre veriler derlenmiştir.

Demir veya çelikten eşya sektörü için Türkiye'nin rekabet gücünü analiz etmek amacıyla Balassa'nın Açıklanmış Karşılaştırmalı Üstünlükler (Revealed Comparative Advantage) (RCA) endeksi ve Vollrath'1n Göreli İhracat Avantajı (The Relative Export Advantage Index) (RXA), Göreli İthalat Nüfuz Endeksi (The Relative Import Penetration Index) (RMP), Göreli Ticari Avantaj (The Relative Trade Avantage Index) (RTA) ve Göreli Rekabet Üstünlüğü (The Relative Comperative Advantage) (RC) endeksleri kullanılmıştır. Analiz ve kıyaslamalar için, Türkiye'ye rakip olan ve dünya ticaretinde önemli ihracat payına sahip olan rakip ülkelere ait veriler esas alınmış ve bu veriler ülkelerarası karşılaştırmaya tabi tutularak değerlendirilmiştir.

Adam Smith'in mutlak üstünlük teorisinin başlangıç noktası olarak kabul edildiği karşılaştırmalı üstünlük, tarihsel süreç içerisinde kavramsal olarak ilk defa David Ricardo tarafından tanımlanmış (Seyidoğlu'dan aktaran Bashimov, 2017: 40), teorik endeks olarak ilk defa Liesner tarafından açıklanmış karşılaştırmalı üstünlük adı ile literatüre kazandırılmış (Bashimov, 2018: 29) ve Balassa tarafından genişletilip geliştirilerek uygulanabilir hale getirilmiştir (Erkan, 2009: 22). Bugün Birleşmiş Milletler ve Dünya Bankası gibi birçok kurum, ülkelerin diş ticarette rekabet güçlerini analiz eden çalışmalarda başvurduğu Açıklanmış Karşılaştırmalı Üstünlükler (RCA) endeksi; bir ürün veya ürün grubuna ait ihracat değerinin, ülkenin genel ihracatı içindeki payının; aynı ürün ya da ürün grubuna ait dünya ihracat değerinin genel dünya ihracatı içindeki payını ifade eder. Balassa (RCA) endeksi, uluslararası ticarette uzmanlaşmayı ölçme kriteri olarak kullanılmaya başlanmıştır (Laursen, 1998: 30). Denklem (1)'de ifade edilen Balassa endeksi;

$\mathrm{RCA}_{\mathrm{ij}}=\left(\mathrm{X}_{\mathrm{ij}} / \mathrm{X}_{\mathrm{j}}\right) /\left(\mathrm{X}_{\mathrm{iw}} / \mathrm{X}_{\mathrm{w}}\right)$ şeklinde formüle edilmektedir.

$\mathrm{Bu}$ endekste $\mathrm{RCA}_{\mathrm{ij}}$; j ülkesinin i malı için açıklanmış karşılaştırmalı üstünlükler endeksini ifade etmektedir. $\mathrm{X}_{\mathrm{ij}}$ : $\mathrm{j}$ ülkesinin i malının ihracat değerini, $\mathrm{X}_{\mathrm{j}}$ : $\mathrm{j}$ ülkesinin genel toplam ihracatı değerini, $\mathrm{X}_{\mathrm{iww}}$ : i malının dünya ihracat değerini, $\mathrm{X}_{\mathrm{w}}$ : dünya toplam ihracat 
değerini belirtmektedir. Balassa Endeksinin 1'den büyük çıkması durumunda, j ülkesinin i malı için uzmanlaştığını ve karşılaştırmalı üstünlüğe sahip olduğu sonucunu verir. Diğer bir deyişle, ilgili malın kendi ülkesindeki toplam ihracatı içindeki oranı, aynı malın dünya ticaretindeki oranından daha büyük olması durumudur. RCA endeksinin 1'den küçük olması durumunda ise, sözkonusu malda karşılaştırmalı üstünlüğe sahip olunamadığı ve uzmanlaşılamadığı sonucuna varılmaktadır (Balassa, 1965: 33).

Balassa tarafından ortaya koyulan açıklanmış karşılaştırmalı üstünlük endeksinin bazı eksiklikleri olduğunu belirten Vollrath (1991: 265), Balassa'nın RCA endeksi üzerinde bir takım revizyonlar yaparak rekabet gücü ölçümü için yeni analiz endeksleri geliştirmiştir. Bunlar sırasıyla; Göreli İhracat Avantajı (RXA), Göreli İthalat Nüfuz (RMP) endeksi, Göreli Ticari Avantaj (RTA) ve Göreli Rekabet Üstünlüğü (RC) endeksleridir.

Vollrath ilk ölçüm yöntemi olarak RXA değerini hesap ederken; öncelikle analize konu olan ürünün değeri $\left(X_{i j}: \mathrm{j}\right.$ ülkesinin $\mathrm{i}$ ürün ihracatı), ülkenin toplam ihracatından arındırılmaktadır ( $X_{n j}$ : j ülkesinin i hariç geriye kalan ihracatı). Benzer şekilde söz konusu ürünün dünya ihracat değerinden ilgili ülkenin bu ürün ihracatı arındırılmakta ( $X_{i r}$ : ilgili ülke hariç dünyanın geri kalanının i ürün ihracat1), ilgili ülke toplam ihracatı dünya toplam ihracatından arındırılmaktadır ( $X_{m r}$ : ilgili ülkenin toplam ihracatı hariç dünyanın geri kalanı). Daha sonra ilgili ürünün ülke uzmanlaşması, dünya uzmanlaşmasına oranlanmaktadır. Böylelikle bu ürüne ait verilerin çift kez hesaplanmasının önüne geçilmiştir. Denklem (2)'de belirtilen ilgili bu hesaplama;

$\mathrm{RXA}_{\mathrm{ij}}=\left(\mathrm{X}_{\mathrm{ij}} / \mathrm{X}_{\mathrm{nj}}\right) /\left(\mathrm{X}_{\mathrm{ir}} / \mathrm{X}_{\mathrm{nr}}\right)$ şeklinde formüle edilmektedir.

Vollrath'ın ikinci ölçüm yöntemi olan Göreli İthalat Nüfuz (RMP) endeksi, denklem (3)'te gösterildiği gibi, ilgili ürün veya sektöre ait ithalat değerinin sözkonusu ülke ithalatı içindeki payının, ilgili sektöre ait dünyadaki ithalat değerinin dünya ithalatı içindeki payına oranıdır.

$\operatorname{RMP}_{\mathrm{ij}}=\left(\mathrm{M}_{\mathrm{ij}} / \mathrm{M}_{\mathrm{nj}}\right) /\left(\mathrm{M}_{\mathrm{ir}} / \mathrm{M}_{\mathrm{nr}}\right)$ şeklinde formüle edilmektedir.

$\mathrm{M}_{\mathrm{ij}}: \mathrm{j}$ ülkesine ait i malının ithalat değeri, $M_{n j}: \mathrm{j}$ ülkesinin i ürünü hariç toplam ithalat değeri, $M_{i r}$ : i malına ait j ülkesinin ithalatı hariç dünya ithalat değeri, $M_{n r}$ : j ülkesinin ithalatı 


\section{Fidan, $\boldsymbol{H}$.}

hariç dünya toplam ithalat değerini ifade etmektedir. RMP $>1$ ise ilgili ülke açısından rekabetin avantajlı olmadığı, RM $<1$ ise ilgili ülke için rekabetçi bir avantajın olduğu kabul edilmektedir.

Vollrath'ın ortaya koyduğu diğer ölçüm yöntemi denklem (4)'te gösterildiği gibi Göreli Ticari Avantaj (RTA) endeksidir. Göreli İhracat Avantajı (RXA) ile Göreli İthalat Nüfuz (RMP) endeksi arasındaki farktır.

$\mathrm{RTA}_{\mathrm{ij}}=\mathrm{RXA}_{\mathrm{ij}}-\mathrm{RMP}_{\mathrm{ij}}$ şeklinde formüle edilmektedir.

$\mathrm{Bu}$ farkın pozitif çıkması durumunda rekabet avantajının olduğuna, negatif çıkması halinde ise rekabet dezavantajının olduğuna işaret eder (Aynagöz Çakmak, 2005: 70)

Üçüncü ölçüm yönteminde Vollrath, Göreli Rekabet Üstünlüğü (RC) endeksini tanımlamıştır. Belli bir ülkenin belli bir sektördeki göreli rekabet üstünlügünü göstermektedir. İhracat ve ithalat değerlerinin kıyaslanması esasına dayanır. Hesaplama yöntemi denklem (5)'te gösterilmektedir.

$\mathrm{RC}_{\mathrm{ij}}=\mathrm{Ln}\left(\mathrm{RXA}_{\mathrm{ij}}\right)-\operatorname{Ln}\left(\mathrm{RMP}_{\mathrm{ij}}\right)$ şeklinde formüle edilmektedir.

Vollrath, belli bir ülke veya sektörün karşılaştırmalı üstünlüğünü RC endeksinin daha iyi yansıttığı gerekçesiyle ve hem arz hem talep dengesini kapsaması sebebiyle daha elverişli olduğunu belirtmektedir. Bu endeksin bir takım kısıtlı yönleri de söz konusu olup, ülkeler arasında bilateral ticaretin olmadığı durumlarda çıkan sonuç eksik olmaktadır (Vollrath, 1991: 276). Ülkelerin hem ithalat ve hem de ihracat yaptığı durumlarda bu endeks uygulanabilir sonuç vermektedir. Endeks sonucu RC $>0$ olduğu durumda ilgili mal için karşılaştırmalı avantaj, $\mathrm{RC}<0$ olduğunda ise karşılaştırmalı dezavantaj söz konusu olmaktadır.

\subsection{Dünya Demir veya Çelikten Eşya Ticareti}

2001-2018 yılları arasındaki demir veya çelikten eşya sektörüne ait dünya ihracat verileri incelendiğinde 2009 yılına kadar istikrarlı bir artış seyri izlemiştir. 2009 yılından sonraki yıllarda ise yine aynı artış devam etmiştir. 2008 yılında yaşanan küresel krizin etkisi ile dünya ticaret hacmindeki daralma 2009 yılında etkisini göstermiştir (Yıldırım, 2010: 47). Başlangıç yılı 2001 olmak üzere 2018 yılına kadar ihracat miktar (ton) bazında \%96 artış göstermiştir. Aynı döneme ait ihracat değerleri incelendiğinde 2001 yılında 11,9 milyar dolar seviyesinden 44,5 milyar dolar seviyesine yükselmiştir. 2001 yılından 2018 yılına kadar olan süre içerisinde yaklaşık üç kat (\%274) artış göstermiştir. Aynı dönemlere ait ithalat verileri de 
ihracat verilerine doğru orantılı olarak artış göstermiştir. 18 yıllık süre içerisinde ithalat miktar bazında 4,6 milyon ton seviyesinden \%119 artışla 10 milyon ton seviyesine yükselmiştir. İthalat değeri ise 12,5 milyar dolardan \%294 artışla 49,4 milyar seviyesine çıkmıştır (Tablo-1).

Tablo 1. Dünya demir veya çelikten eşya ticareti

\begin{tabular}{|r|r|r|r|r|}
\hline \multicolumn{1}{|c|}{ Y1lar } & İhracat (ton) & \multicolumn{1}{|c|}{ İhracat (bin \$) } & \multicolumn{1}{c|}{ İthalat (ton) } & \multicolumn{1}{c|}{ İthalat (bin \$) } \\
\hline 2001 & 5.197 .401 & 11.895 .318 & 4.602 .793 & 12.560 .357 \\
\hline 2002 & 5.638 .463 & 12.499 .239 & 4.267 .501 & 13.593 .018 \\
\hline 2003 & 5.860 .512 & 14.526 .014 & 5.314 .899 & 15.654 .094 \\
\hline 2004 & 6.920 .808 & 17.224 .049 & 5.879 .845 & 18.366 .201 \\
\hline 2005 & 7.458 .724 & 19.977 .664 & 6.304 .797 & 21.297 .667 \\
\hline 2006 & 8.327 .022 & 23.966 .366 & 7.371 .736 & 24.683 .818 \\
\hline 2007 & 9.225 .046 & 29.315 .496 & 11.622 .918 & 30.180 .767 \\
\hline 2008 & 9.057 .876 & 34.126 .252 & 11.198 .726 & 36.691 .469 \\
\hline 2009 & 6.843 .075 & 25.504 .648 & 6.339 .284 & 27.875 .716 \\
\hline 2010 & 7.885 .797 & 28.811 .096 & 8.271 .659 & 32.694 .027 \\
\hline 2011 & 8.603 .890 & 35.046 .224 & 8.970 .338 & 37.878 .213 \\
\hline 2012 & 8.918 .743 & 36.138 .712 & 9.973 .586 & 38.937 .559 \\
\hline 2013 & 9.167 .142 & 37.914 .558 & 9.166 .825 & 41.482 .393 \\
\hline 2014 & 9.630 .890 & 39.913 .239 & 9.814 .142 & 43.786 .967 \\
\hline 2015 & 9.395 .355 & 37.215 .345 & 9.155 .511 & 41.135 .524 \\
\hline 2016 & 9.187 .067 & 36.305 .945 & 8.722 .966 & 40.866 .576 \\
\hline 2017 & 9.810 .846 & 39.269 .417 & 9.782 .048 & 44.315 .214 \\
\hline 2018 & 10.161 .761 & 44.479 .379 & 10.061 .446 & 49.429 .214 \\
\hline
\end{tabular}

Kaynak: Trademap, 2019

Ülkeler sınıflandırması dikkate alınarak dünya demir veya çelikten eşyalara ait ithalat verileri analiz edilerek ithalatta ilk 10 ülke “Tablo-2'de gösterilmiştir. Elde edilen bu veriler miktar (ton) ölçeğindedir. Hem yıllar bazında ve hem de genel toplamda dünyanın en büyük ithalatçı ülkesi Meksika'dır. 2001-2018 döneminde 25,9 milyon ton ile dünya ithalatının \%18'lik kısmının ülkeye girişini sağlamıştır. 2009 yılında dünya genelinde olduğu gibi Meksika da ithalatını olağandışı bir şekilde düşürmüştür. 18 yıllık veriler toplamı göz önüne alınarak Meksika’yı sırasıyla; Almanya (\%9 pay), ABD (\%7 pay), Japonya (\%5 pay), Fransa ve Güney Kore (\%4 pay), diğer ülkeler Tayland, İngiltere, Avusturya ve Polonya \%3 pay alarak takip etmişlerdir. $\mathrm{Bu}$ ülkelerin 2001 yılındaki ithalatı toplamı 2,7 milyon ton ile dünya ticaretinden aldığı pay \%60 iken, 2018 yılında bu 6,3 milyon ton olarak gerçekleşirken dünya ticaretinden aldığı pay \%58 seviyesinde gerçekleşmiştir. 2001-2018 arasındaki diğer yıllarda da bu oran \%55-60 bandında bir seyir izlemiştir. 
Fidan, $\boldsymbol{H}$.

Tablo 2. İlk 10 ithalatçı ülkeye ait veriler (ton)

\begin{tabular}{|c|c|c|c|c|c|c|c|c|c|c|}
\hline Yillar & Meksika & Almanya & $\mathrm{ABD}$ & Japonya & Fransa & G. Kore & Tayland & İngiltere & Avusturya & Polonya \\
\hline 2001 & 752.779 & 622.015 & 430.174 & 198.004 & 268.697 & 46.962 & 73.360 & 114.823 & 136.243 & 97.341 \\
\hline 2002 & 868.116 & 599.915 & 440.000 & 243.517 & 281.627 & 84.742 & 76.203 & 138.673 & 125.921 & 123.626 \\
\hline 2003 & 809.855 & 618.642 & 440.571 & 293.693 & 309.810 & 100.217 & 95.380 & 171.491 & 147.563 & 168.367 \\
\hline 2004 & 838.454 & 619.248 & 455.849 & 346.608 & 320.814 & 136.407 & 101.648 & 203.190 & 165.823 & 163.674 \\
\hline 2005 & 831.342 & 680.958 & 529.161 & 408.950 & 343.650 & 175.316 & 114.010 & 175.605 & 161.069 & 181.305 \\
\hline 2006 & 878.221 & 734.690 & 851.349 & 448.061 & 381.896 & 229.292 & 130.249 & 210.486 & 184.392 & 216.421 \\
\hline 2007 & 1.132 .533 & 776.392 & 837.262 & 452.044 & 431.491 & 315.528 & 168.708 & 307.225 & 226.410 & 352.714 \\
\hline 2008 & 3.641 .726 & 835.275 & 467.736 & 445.710 & 405.474 & 319.607 & 267.359 & 266.274 & 242.107 & 237.253 \\
\hline 2009 & 563.606 & 546.706 & 509.523 & 331.129 & 308.804 & 328.985 & 177.994 & 167.266 & 186.411 & 172.779 \\
\hline 2010 & 1.106 .509 & 677.219 & 607.877 & 404.300 & 356.004 & 397.741 & 241.085 & 202.387 & 246.831 & 185.578 \\
\hline 2011 & 1.318 .860 & 827.545 & 643.666 & 434.840 & 410.605 & 397.241 & 274.259 & 213.864 & 287.044 & 210.906 \\
\hline 2012 & 3.005 .729 & 799.396 & 699.599 & 422.909 & 385.306 & 414.149 & 342.729 & 202.591 & 270.739 & 191.965 \\
\hline 2013 & 1.588 .526 & 777.854 & 682.259 & 420.745 & 390.421 & 432.492 & 343.015 & 200.203 & 284.127 & 214.907 \\
\hline 2014 & 1.522 .015 & 881.808 & 747.868 & 424.241 & 396.619 & 416.914 & 361.364 & 247.337 & 293.171 & 227.819 \\
\hline 2015 & 1.350 .187 & 867.829 & 799.890 & 404.442 & 380.352 & 448.778 & 370.924 & 237.060 & 296.809 & 233.634 \\
\hline 2016 & 1.516 .951 & 905.876 & 237.340 & 388.219 & 396.293 & 483.897 & 369.381 & 277.207 & 297.764 & 282.302 \\
\hline 2017 & 2.244 .284 & 968.908 & 167.884 & 399.706 & 414.795 & 477.075 & 388.665 & 254.978 & 326.705 & 293.343 \\
\hline 2018 & 1.973 .513 & 1.019 .776 & 283.568 & 415.603 & 435.261 & 458.923 & 496.354 & 632.630 & 341.634 & 294.664 \\
\hline Toplam & 25.943 .206 & 13.760 .052 & 9.831 .576 & 6.882 .721 & 6.617 .919 & 5.664 .266 & 4.392 .687 & 4.223 .290 & 4.220 .763 & 3.848 .598 \\
\hline Pay1 & $18 \%$ & $9 \%$ & $7 \%$ & $5 \%$ & $4 \%$ & $4 \%$ & $3 \%$ & $3 \%$ & $3 \%$ & $3 \%$ \\
\hline
\end{tabular}

Kaynak: Trademap, 2019 (toplam ve yüzdesel veriler yazar tarafından hesaplanmıştır)

Dünya demir veya eşya ürünlerinin ihracatında pay sahibi olan ülkelere bakıldığında sırasıyla Çin (\%15), Almanya (12), ABD (\%8), İtalya (\%6), Fransa (\%4), Güney Kore (\%4), Polonya (\%4), Çek Cumhuriyeti, Taylan ve Tayvan (\%3), Avusturya ve Hollanda (\%2) oranlarıyla dünya ihracat sıralamasında ilk siralarda yer almaktadırlar. Bu ülkeler dünya ihracatının \%67'sini karşılamaktadırlar. Dünya demir veya çelikten eşya ürünleri ihracatında ilk sıralarda yer alan 7 AB ülkesi analizlerimize dahil edilmiştir.

Türkiye'nin rekabet gücü analizlerimizde ele alacağımız ülkelerin ihracat değerleri Tablo-3'te gösterilmiştir. 2018 yılında Almanya, İtalya ve Fransa'nın dünya ihracat paylarında \% 1,5 oranında bir azalma görülürken, diğer ülkelerin ihracat oranlarında artış gözlemlenmiştir. Oransal bazda en çok artış \%1,5 ile Polonya tarafından gerçekleştirilmiştir. Bu ülkelerin 2018 yılı verilerine göre dünya ihracatından aldıkları pay \%34,70’tir. Bu oran 2007 yılında en yüksek seviyede $(\% 40,89)$ gerçekleşmiştir. 2018 yılına ait veriler esas olmak üzere, Türkiye dünya 
sıralamasında 18. sırada yer almaktadır. 17. büyük ihracatçı konumunda bulunan Hindistan, Türkiye ile sürekli yer değiştirmektedir.

Tablo 3. En çok ihracat yapan ülkelerden rakibimiz olan ülkeler (bin \$)

\begin{tabular}{|r|c|c|c|r|r|r|r|}
\hline Yllar & Almanya & İtalya & Fransa & \multicolumn{1}{c|}{ Polonya } & \multicolumn{1}{c}{ Çek } & Avusturya & Hollanda \\
\hline 2001 & 1.567 .578 & 959.934 & 645.202 & 270.977 & 290.335 & 237.601 & 255.965 \\
\hline 2002 & 1.728 .977 & 1.005 .086 & 698.829 & 295.259 & 314.838 & 270.489 & 285.846 \\
\hline 2003 & 1.943 .090 & 1.203 .076 & 870.959 & 447.208 & 441.476 & 383.836 & 384.730 \\
\hline 2004 & 2.322 .227 & 1.508 .025 & 935.757 & 561.821 & 596.112 & 446.747 & 430.001 \\
\hline 2005 & 2.862 .086 & 1.830 .531 & 1.036 .922 & 593.700 & 670.302 & 488.980 & 463.020 \\
\hline 2006 & 3.465 .967 & 2.248 .615 & 1.150 .403 & 758.788 & 764.062 & 540.274 & 622.918 \\
\hline 2007 & 4.028 .425 & 2.930 .139 & 1.532 .738 & 890.619 & 996.504 & 808.672 & 800.887 \\
\hline 2008 & 4.693 .646 & 3.413 .381 & 1.690 .359 & 1.095 .118 & 1.189 .003 & 1.012 .429 & 909.354 \\
\hline 2009 & 3.401 .738 & 2.392 .931 & 1.274 .424 & 658.094 & 750.052 & 722.881 & 662.211 \\
\hline 2010 & 3.798 .458 & 2.194 .952 & 1.216 .191 & 738.337 & 834.374 & 860.706 & 664.211 \\
\hline 2011 & 4.701 .099 & 2.711 .556 & 1.450 .098 & 1.036 .774 & 1.197 .792 & 1.081 .754 & 912.521 \\
\hline 2012 & 4.523 .778 & 2.586 .985 & 1.282 .790 & 969.387 & 1.149 .599 & 955.030 & 814.442 \\
\hline 2013 & 4.725 .722 & 2.798 .891 & 1.367 .008 & 1.076 .440 & 1.289 .421 & 970.342 & 908.187 \\
\hline 2014 & 4.957 .950 & 2.889 .754 & 1.407 .089 & 1.178 .320 & 1.412 .586 & 1.122 .268 & 939.874 \\
\hline 2015 & 4.249 .373 & 2.482 .991 & 1.184 .449 & 1.054 .614 & 1.196 .770 & 784.525 & 866.113 \\
\hline 2016 & 4.176 .152 & 2.314 .828 & 1.216 .943 & 1.024 .854 & 1.244 .104 & 741.104 & 825.892 \\
\hline 2017 & 4.690 .559 & 2.578 .431 & 1.481 .515 & 1.213 .944 & 1.422 .425 & 853.648 & 999.733 \\
\hline 2018 & 5.135 .517 & 2.914 .025 & 1.784 .279 & 1.680 .341 & 1.587 .712 & 1.186 .690 & 1.147 .140 \\
\hline
\end{tabular}

Kaynak: Trademap, 2019

\subsection{Türkiye Demir veya Çelikten Eşya Dış Ticareti}

Türkiye'nin demir veya çelikten eşya ihracat ve ithalat verileri Şekil-1 üzerinde belirtilmiştir. 2007 yılı hariç olmak üzere genel olarak değerlendirildiğinde yukarı yönlü düzenli bir artış eğiliminde gerçekleştiği görülmektedir. 2003 öncesi diş ticaret açığı varken, 2003 sonrasında dış ticaret fazlası veriler elde edilmiştir. 2001 küresel ekonomik krizin etkileri ile değer kaybeden Türk Lirası, ihracatımıza olumlu katkı sağlamış (Altay ve Gürpınar, 2008: 262) ve 2003 yılında yakaladığımız ihracat artışı günümüze kadar süregelmiştir. 2001 ve 2018 verileri incelendiğinde ihracat 20 kat artarken, ithalat 13 kat artış göstermiştir. 2018 yılında hem ithalat hem de ihracat verileri en üst düzeyde gerçekleşmiştir. Bu y1l verilerine göre cari fazla son on yılın en düşük seviyesinde kalmıştır. 2014 yılında ihracatın ithalatı karşılama oranı \%238 ile analiz döneminin en yüksek oranına ulaşmıştır. 2001 yılında demir veya çelikten eşyaların toplam ihracat içindeki payı \%0,12 iken bu oran 2018 yılında \%0,45 olmuştur. Bu sonuçlara göre demir veya çelikten eşya ihracatının toplam ihracat içerisindeki payı yaklaşık olarak 4 kat artış göstermiştir. Trademap verilerine göre; 2001 yılında Türkiye'nin bu ürünler ihracatının 
Fidan, $\boldsymbol{H}$.

dünya ihracatındaki payı \%0,31 iken, 2018 yılında \%1,71 olarak gerçekleşmiştir. Türkiye'nin söz konusu ürünlere ait ihracatı 5,5 kat artmıştır.

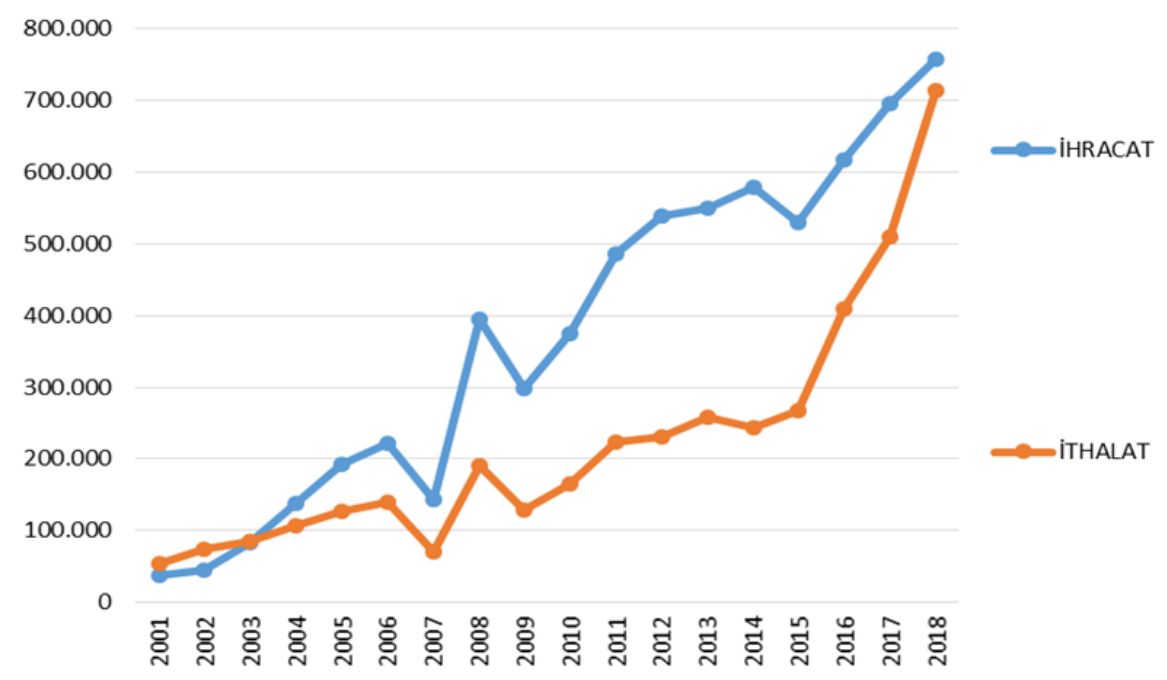

Şekil 1. 2001-2018 dönemi Türkiye demir veya çelikten eşya ürünleri dış ticareti durumu

Kaynak: Trademap, 2019

Türkiye'nin demir veya çelikten eşya ihracatı 2001-2018 döneminde ortalama 371 milyon dolardır. Türkiye İstatistik Kurumu (TÜİK) verilerine göre, söz konusu ürünler için ihracatımızda $\mathrm{AB}$ ülkelerinin payı \%57'dir. İlgili döneme ait toplam ihracat verileri değerlendirildiğinde Almanya \%22 pay ile ilk sırada yer almaktadır. Almanya’yı diğer AB üyesi İngiltere, Fransa ve İtalya takip etmektedir (Şekil-2). Almanya'ya yapılan ihracatımız 1,46 milyar dolar iken Fransa'ya 515 milyon dolar, Irak'a 360 milyon dolardır. Son yıllarda Körfez ülkelerine yapılan ihracatta kayda değer artışların olduğu verilere yansımaktadır.

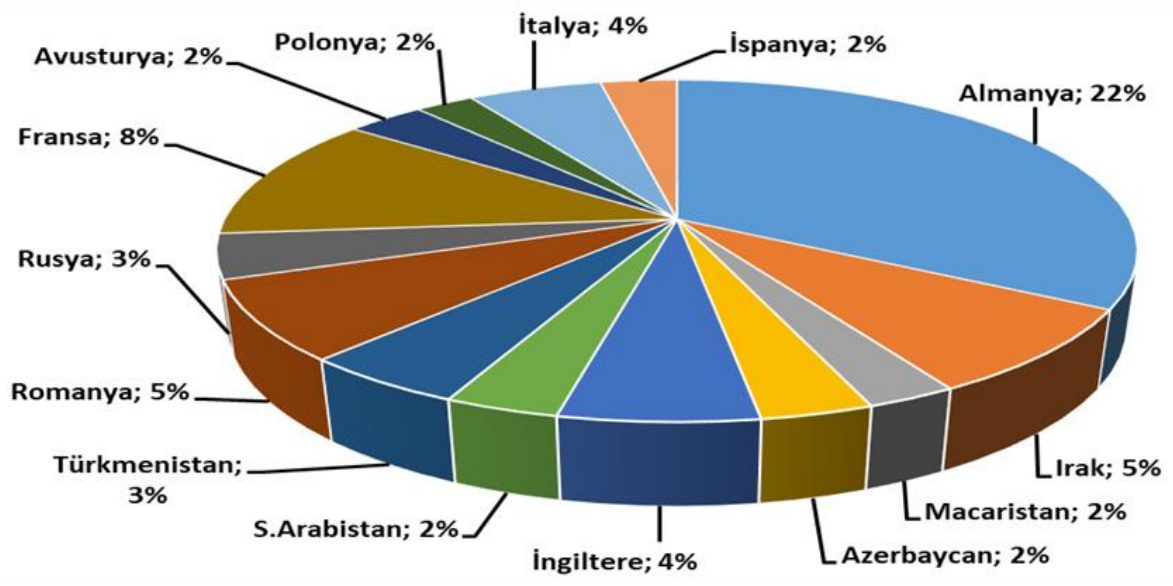

Şekil 1. 2001-2018 dönemi toplamında, sektör ihracat değerinin ülkelere göre dağılımı

Kaynak: Trademap, 2019 


\section{BULGULAR}

Balassa'nın AKÜ endeks değerinin yüksek olması ilgili ülkenin rekabet edebilme gücünün güçlü olması anlamına gelmektedir. Rekabet edilebilirliği hakkında anlamlı bir değerlendirme yapabilmek için endeks değerinin 1'den büyük olması gerekmektedir. 2003 yılına kadarki yıllarda Türkiye'nin rekabet gücü yok iken, bu tarihten sonraki yıllarda (2007 istisna) rekabet gücüne sahip olmuştur. Türkiye'nin rakibi olan ülkelerle karşılaştırıldığında, Hollanda ve Fransa'ya karşı rekabet üstünlüğünün olduğu; İtalya, Polonya, Çek Cumhuriyeti ve Avusturya'ya karşı rekabette geri kaldığı ve Almanya ile yakın bir rekabet gücüne sahip olduğu görülmektedir. Türkiye'nin AKÜ endeksi 2001-2018 döneminde \%223 oranında artış gösterirken, Almanya \%2, İtalya \%15, Fransa \%19, Avusturya \%52 ve Hollanda \%40 oranında rekabet gücü artışı sağlarken, Polonya \%29 ve Çek Cumhuriyeti \%29 oranında rekabet gücü kaybı yaşamıştır. Tüm yıllar göz önüne alındığında sektörde en güçlü rekabet avantajının Çek Cumhuriyeti olduğu görülmektedir (Tablo-4).

Tablo 4. Açıklanmış karşılaştırmalı üstünlük endeksi (RCA) (Balassa)

\begin{tabular}{|c|c|c|c|c|c|c|c|c|}
\hline Y1lar & Türkiye & Almanya & Italya & Fransa & Polonya & Çek Cum. & Avusturya & Hollanda \\
\hline 2001 & 0,61 & 1,41 & 2,02 & 1,15 & 3,95 & 4,48 & 1,84 & 0,61 \\
\hline 2002 & 0,64 & 1,44 & 2,03 & 1,18 & 3,77 & 3,66 & 1,9 & 0,67 \\
\hline 2003 & 0,91 & 1,34 & 2,07 & 1,25 & 4,37 & 4,67 & 2,22 & 0,75 \\
\hline 2004 & 1,15 & 1,35 & 2,25 & 1,2 & 4,02 & 4,79 & 2,13 & 0,71 \\
\hline 2005 & 1,36 & 1,52 & 2,54 & 1,24 & 3,44 & 4,44 & 2,15 & 0,69 \\
\hline 2006 & 1,29 & 1,54 & 2,69 & 1,2 & 3,45 & 4,01 & 2,01 & 0,78 \\
\hline 2007 & 0,63 & 1,43 & 2,76 & 1,34 & 3,03 & 3,89 & 2,44 & 0,79 \\
\hline 2008 & 1,4 & 1,5 & 2,95 & 1,33 & 2,98 & 3,81 & 2,75 & 0,78 \\
\hline 2009 & 1,42 & 1,46 & 2,85 & 1,33 & 2,33 & 3,22 & 2,66 & 0,74 \\
\hline 2010 & 1,72 & 1,57 & 2,57 & 1,25 & 2,46 & 3,31 & 3,11 & 0,71 \\
\hline 2011 & 1,86 & 1,64 & 2,68 & 1,28 & 2,85 & 3,81 & 3,29 & 0,89 \\
\hline 2012 & 1,8 & 1,63 & 2,62 & 1,17 & 2,75 & 3,74 & 3,06 & 0,75 \\
\hline 2013 & 1,8 & 1,62 & 2,69 & 1,2 & 2,63 & 3,97 & 2,9 & 0,79 \\
\hline 2014 & 1,74 & 1,57 & 2,58 & 1,18 & 2,6 & 3,82 & 2,98 & 0,78 \\
\hline 2015 & 1,63 & 1,41 & 2,4 & 1,06 & 2,39 & 3,34 & 2,26 & 0,87 \\
\hline 2016 & 1,89 & 1,36 & 2,2 & 1,09 & 2,28 & 3,35 & 2,13 & 0,81 \\
\hline 2017 & 1,98 & 1,45 & 2,29 & 1,27 & 2,45 & 3,49 & 2,27 & 0,88 \\
\hline 2018 & 1,96 & 1,43 & 2,33 & 1,37 & 2,79 & 3,41 & 2,79 & 0,85 \\
\hline Ortalama & 1,43 & 1,48 & 2,47 & 1,23 & 3,03 & 3,84 & 2,5 & 0,77 \\
\hline
\end{tabular}

Kaynak: Trademap, 2019 verileri esas alınarak hesaplanmıştır. 
Balassa'nın RCA endeksi ile Vollrath'ın göreli ihracat avantajı RXA endeksi hesaplama yöntemi arasındaki fark; Vollrath, ülkenin ihracat değerlerini dünyanın ihracat değerlerinden arındırması sebebiyledir. Ülkenin ihracat değerleri çift kez hesaplamaya tabi tutulmamıştır. Bu haliyle Tablo-4'te hesaplanan RCA değeri ile Tablo-5'te hesaplanan RXA değerleri birbiriyle tutarlidir.

Tablo 5. Göreli ihracat avantaj1 endeksi (RXA) (Vollrath)

\begin{tabular}{|c|c|c|c|c|c|c|c|c|}
\hline Y1llar & Türkiye & Almanya & İtalya & Fransa & Polonya & Çek Cum. & Avusturya & Hollanda \\
\hline 2001 & 0,61 & 1,48 & 2,12 & 1,16 & 4,05 & 4,61 & 1,86 & 0,6 \\
\hline 2002 & 0,64 & 1,52 & 2,13 & 1,19 & 3,87 & 3,75 & 1,93 & 0,66 \\
\hline 2003 & 0,92 & 1,39 & 2,18 & 1,27 & 4,51 & 4,83 & 2,26 & 0,74 \\
\hline 2004 & 1,15 & 1,4 & 2,38 & 1,21 & 4,16 & 4,97 & 2,17 & 0,71 \\
\hline 2005 & 1,36 & 1,61 & 2,71 & 1,25 & 3,54 & 4,6 & 2,19 & 0,68 \\
\hline 2006 & 1,3 & 1,64 & 2,88 & 1,21 & 3,56 & 4,14 & 2,04 & 0,77 \\
\hline 2007 & 0,63 & 1,5 & 2,98 & 1,36 & 3,11 & 4,02 & 2,49 & 0,79 \\
\hline 2008 & 1,41 & 1,58 & 3,19 & 1,35 & 3,07 & 3,94 & 2,82 & 0,78 \\
\hline 2009 & 1,43 & 1,54 & 3,06 & 1,35 & 2,38 & 3,31 & 2,73 & 0,74 \\
\hline 2010 & 1,74 & 1,66 & 2,72 & 1,26 & 2,51 & 3,4 & 3,2 & 0,7 \\
\hline 2011 & 1,88 & 1,74 & 2,83 & 1,29 & 2,92 & 3,94 & 3,39 & 0,89 \\
\hline 2012 & 1,82 & 1,73 & 2,76 & 1,18 & 2,81 & 3,86 & 3,13 & 0,75 \\
\hline 2013 & 1,82 & 1,72 & 2,84 & 1,21 & 2,69 & 4,11 & 2,97 & 0,79 \\
\hline 2014 & 1,76 & 1,65 & 2,72 & 1,18 & 2,66 & 3,95 & 3,06 & 0,77 \\
\hline 2015 & 1,64 & 1,47 & 2,51 & 1,06 & 2,45 & 3,45 & 2,3 & 0,87 \\
\hline 2016 & 1,92 & 1,42 & 2,29 & 1,1 & 2,33 & 3,46 & 2,17 & 0,81 \\
\hline 2017 & 2,01 & 1,52 & 2,39 & 1,28 & 2,51 & 3,61 & 2,31 & 0,88 \\
\hline 2018 & 1,99 & 1,5 & 2,44 & 1,38 & 2,88 & 3,53 & 2,86 & 0,85 \\
\hline Ortalama & 1,45 & 1,56 & 2,62 & 1,24 & 3,11 & 3,97 & 2,55 & 0,77 \\
\hline
\end{tabular}

Kaynak: Trademap, 2019 verileri esas alınarak hesaplanmıştır.

Göreli İthalat Nüfuz (RMP) endeksinin 1'den küçük olması ülke veya sektör açısından olumlu değerlendirilerek rekabet avantajının olduğu sonucuna varılmaktadır. Tablo-6'da dünya ticaretinde birbirine rakip olan ülkelerin RMP değerleri 1'in altında çıkmıştır. Bu durum göstermektedir ki; ülkelerin birbirine karşı bariz bir rekabet avantajına sahip değildir. Ortalama endeks üzerinden ülkelerin kendi aralarında bir kıyaslama yapılacak olursa, Türkiye ve İtalya diğer ülkelere göre daha avantajlı durumdadır. Türkiye'nin RMP endeksi 2018 y1lında 2001 yılına göre \%119 oranında artış göstermiştir. Türkiye bu dönemde giderek dezavantajlı yükselişine devam etmiştir. Bu dönemde avantaj kazanımını arttıran tek ülke (\%2 endeks düşüş oranıyla) Çek Cumhuriyeti olmuştur. Diğer bir bakış açısına göre; göreli ihracat avantajı (RXA) tablosunda rekabetçi avantaja sahip olan ülkelerin göreli ithalat nüfuz (RMP) endeksinde 
dezavantajlı oldukları görülmektedir. Diğer bir deyişle yüksek ihracat oranına sahip olan ülkelerin aynı zamanda yüksek ithalat oranına sahip oldukları sonucu ortaya çıkmaktadır.

Tablo 6. Göreli ithalat nüfuz endeksi (RMP) (Vollrath)

\begin{tabular}{|c|c|c|c|c|c|c|c|c|}
\hline Yillar & Türkiye & Almanya & İtalya & Fransa & Polonya & Çek Cum. & Avusturya & Hollanda \\
\hline 2001 & 0,0019 & 0,0024 & 0,0012 & 0,0023 & 0,0056 & 0,0084 & 0,005 & 0,0016 \\
\hline 2002 & 0,0019 & 0,0025 & 0,0012 & 0,0024 & 0,0067 & 0,007 & 0,0048 & 0,0017 \\
\hline 2003 & 0,0016 & 0,0024 & 0,0012 & 0,0025 & 0,0082 & 0,009 & 0,0049 & 0,0016 \\
\hline 2004 & 0,0014 & 0,0024 & 0,0012 & 0,0024 & 0,0076 & 0,0085 & 0,0051 & 0,0014 \\
\hline 2005 & 0,0013 & 0,0026 & 0,0013 & 0,0025 & 0,0085 & 0,0084 & 0,0052 & 0,0013 \\
\hline 2006 & 0,0012 & 0,0025 & 0,0014 & 0,0025 & 0,0079 & 0,0084 & 0,0056 & 0,0014 \\
\hline 2007 & 0,0005 & 0,0028 & 0,0015 & 0,0028 & 0,0072 & 0,0087 & 0,0066 & 0,0016 \\
\hline 2008 & 0,0012 & 0,003 & 0,0017 & 0,0028 & 0,0066 & 0,0091 & 0,0074 & 0,0017 \\
\hline 2009 & 0,0011 & 0,0025 & 0,0015 & 0,0028 & 0,006 & 0,0079 & 0,0066 & 0,0015 \\
\hline 2010 & 0,0011 & 0,0025 & 0,0016 & 0,0026 & 0,0053 & 0,0073 & 0,0073 & 0,0014 \\
\hline 2011 & 0,0011 & 0,0027 & 0,0017 & 0,0027 & 0,0053 & 0,0074 & 0,0072 & 0,0016 \\
\hline 2012 & 0,0012 & 0,0028 & 0,0016 & 0,0027 & 0,0053 & 0,0072 & 0,0073 & 0,0015 \\
\hline 2013 & 0,0012 & 0,0028 & 0,0017 & 0,0029 & 0,0056 & 0,0081 & 0,0075 & 0,0017 \\
\hline 2014 & 0,0012 & 0,0031 & 0,0018 & 0,003 & 0,0058 & 0,0082 & 0,0075 & 0,0019 \\
\hline 2015 & 0,0016 & 0,0032 & 0,002 & 0,003 & 0,0061 & 0,0082 & 0,0078 & 0,0023 \\
\hline 2016 & 0,0026 & 0,0033 & 0,0022 & 0,003 & 0,0064 & 0,0084 & 0,0079 & 0,0021 \\
\hline 2017 & 0,0027 & 0,0033 & 0,0021 & 0,003 & 0,006 & 0,0081 & 0,0082 & 0,0021 \\
\hline 2018 & 0,0041 & 0,0035 & 0,0021 & 0,0032 & 0,0057 & 0,0083 & 0,0088 & 0,0021 \\
\hline Ortalama & 0,0016 & 0,0028 & 0,0016 & 0,0027 & 0,0064 & 0,0081 & 0,0067 & 0,0017 \\
\hline
\end{tabular}

Kaynak: Trademap, 2019 verileri esas alınarak hesaplanmıştır.

Vollrath'ın rekabet gücü ölçümü ve değerlendirmesinde kullandığı diğer yöntem göreli ticaret avantajı endeksidir (RTA). Bu endeksten ortaya çıkan göstergenin pozitif bir değer alması halinde ticaret avantajının olduğu, negatif bir değer alması durumunda ise ticaret dezavantajının olduğunu belirtir. Tablo-7'de analize tabi tutulan ülkelerin tamamı dünya ticaretinde ticaret avantajına sahiptir. 2001-2018 döneminde ülkelerin hiçbiri ticari dezavantaj pozisyonuna düşmemiştir. Hem Balassa'nın AKÜ endeksine ve hem de Vollrath'ın RXA endeksine paralellik göstermektedir. En güçlü rekabet avantajına sahip ülke sıralamaları örtüşmektedir. Bu dönemde, Polonya ve Çek Cumhuriyeti'nin avantaj kaybettiği, Almanya'nın durağan bir seyir izlediği, diğer ülkelerin ise avantaj kazandıkları sonucu ortaya çıkmaktadır. 
Fidan, $\boldsymbol{H}$.

Tablo 7. Göreli ticaret avantajı endeksi (RTA) (Vollrath)

\begin{tabular}{|c|c|c|c|c|c|c|c|c|}
\hline Yillar & Türkiye & Almanya & İtalya & Fransa & Polonya & $\begin{array}{r}\text { Çek } \\
\text { Cum. }\end{array}$ & Avusturya & Hollanda \\
\hline 2001 & 0,6 & 1,48 & 2,12 & 1,16 & 4,04 & 4,6 & 1,86 & 0,6 \\
\hline 2002 & 0,63 & 1,52 & 2,13 & 1,19 & 3,86 & 3,74 & 1,92 & 0,66 \\
\hline 2003 & 0,91 & 1,39 & 2,17 & 1,27 & 4,51 & 4,82 & 2,25 & 0,74 \\
\hline 2004 & 1,15 & 1,4 & 2,38 & 1,21 & 4,15 & 4,96 & 2,16 & 0,71 \\
\hline 2005 & 1,36 & 1,6 & 2,71 & 1,25 & 3,53 & 4,59 & 2,18 & 0,68 \\
\hline 2006 & 1,29 & 1,64 & 2,88 & 1,21 & 3,55 & 4,13 & 2,03 & 0,77 \\
\hline 2007 & 0,63 & 1,5 & 2,98 & 1,36 & 3,1 & 4,02 & 2,48 & 0,78 \\
\hline 2008 & 1,41 & 1,58 & 3,18 & 1,35 & 3,06 & 3,94 & 2,82 & 0,77 \\
\hline 2009 & 1,43 & 1,53 & 3,06 & 1,35 & 2,37 & 3,3 & 2,72 & 0,74 \\
\hline 2010 & 1,74 & 1,65 & 2,72 & 1,26 & 2,51 & 3,39 & 3,19 & 0,7 \\
\hline 2011 & 1,88 & 1,74 & 2,83 & 1,29 & 2,91 & 3,93 & 3,38 & 0,88 \\
\hline 2012 & 1,82 & 1,73 & 2,76 & 1,17 & 2,8 & 3,85 & 3,13 & 0,74 \\
\hline 2013 & 1,82 & 1,71 & 2,84 & 1,21 & 2,68 & 4,1 & 2,96 & 0,79 \\
\hline 2014 & 1,75 & 1,65 & 2,72 & 1,18 & 2,66 & 3,94 & 3,05 & 0,77 \\
\hline 2015 & 1,64 & 1,47 & 2,51 & 1,06 & 2,44 & 3,44 & 2,3 & 0,87 \\
\hline 2016 & 1,92 & 1,41 & 2,29 & 1,09 & 2,33 & 3,45 & 2,16 & 0,81 \\
\hline 2017 & 2,01 & 1,51 & 2,39 & 1,28 & 2,51 & 3,61 & 2,3 & 0,88 \\
\hline 2018 & 1,99 & 1,49 & 2,44 & 1,38 & 2,87 & 3,52 & 2,85 & 0,85 \\
\hline Ortalama & 1,44 & 1,56 & 2,62 & 1,24 & 3,1 & 3,96 & 2,54 & 0,76 \\
\hline
\end{tabular}

Kaynak: Trademap, 2019 verileri esas alınarak hesaplanmıştır.

Rekabet üstünlüğü endeksinin (RC) pozitif yönde yüksek çıkması, ilgili ülke veya sektörün göreli rekabet üstünlüğüne sahip olduğu anlamı taşımaktadır. Tablo-8'de görüldüğü gibi Türkiye dahil tüm ülkelerin RC endeks değeri pozitif yönlü yükssek sonuç vermiştir. Tablo değerleri esas alındığında Türkiye, İtalya'dan sonra en güçlü göreli rekabet üstünlüğüne sahiptir. 2001-2018 dönemi baz alındığında rekabet üstünlüğünü arttıran iki ülkeden biri Türkiye (diğeri Hollanda) olmuştur. Diğer ülkeler göreli rekabet üstünlügü kaybı yaşamışlardır. 
Tablo 8. Göreli rekabet üstünlüğü endeksi (RC) (Vollrath)

\begin{tabular}{|c|c|c|c|c|c|c|c|c|}
\hline Yillar & Türkiye & Almanya & İtalya & Fransa & Polonya & Çek Cum. & Avusturya & Hollanda \\
\hline 2001 & 5,78 & 6,41 & 7,48 & 6,24 & 6,58 & 6,3 & 5,91 & 5,91 \\
\hline 2002 & 5,79 & 6,4 & 7,48 & 6,21 & 6,35 & 6,29 & 6 & 5,99 \\
\hline 2003 & 6,37 & 6,37 & 7,46 & 6,23 & 6,31 & 6,28 & 6,13 & 6,11 \\
\hline 2004 & 6,75 & 6,38 & 7,57 & 6,23 & 6,3 & 6,37 & 6,05 & 6,2 \\
\hline 2005 & 6,93 & 6,43 & 7,63 & 6,22 & 6,03 & 6,31 & 6,04 & 6,25 \\
\hline 2006 & 6,97 & 6,47 & 7,64 & 6,17 & 6,11 & 6,2 & 5,89 & 6,3 \\
\hline 2007 & 7,14 & 6,3 & 7,56 & 6,19 & 6,07 & 6,14 & 5,93 & 6,17 \\
\hline 2008 & 7,1 & 6,27 & 7,53 & 6,17 & 6,14 & 6,07 & 5,95 & 6,14 \\
\hline 2009 & 7,14 & 6,43 & 7,63 & 6,16 & 5,98 & 6,03 & 6,03 & 6,18 \\
\hline 2010 & 7,38 & 6,5 & 7,46 & 6,17 & 6,17 & 6,14 & 6,09 & 6,23 \\
\hline 2011 & 7,45 & 6,47 & 7,43 & 6,17 & 6,31 & 6,27 & 6,15 & 6,3 \\
\hline 2012 & 7,35 & 6,43 & 7,44 & 6,07 & 6,27 & 6,28 & 6,06 & 6,23 \\
\hline 2013 & 7,3 & 6,41 & 7,42 & 6,04 & 6,17 & 6,23 & 5,99 & 6,13 \\
\hline 2014 & 7,27 & 6,28 & 7,31 & 5,99 & 6,14 & 6,18 & 6 & 6,02 \\
\hline 2015 & 6,93 & 6,14 & 7,15 & 5,89 & 6 & 6,05 & 5,69 & 5,94 \\
\hline 2016 & 6,6 & 6,07 & 6,93 & 5,9 & 5,9 & 6,02 & 5,61 & 5,94 \\
\hline 2017 & 6,62 & 6,13 & 7,02 & 6,06 & 6,04 & 6,1 & 5,64 & 6,02 \\
\hline 2018 & 6,18 & 6,07 & 7,06 & 6,08 & 6,22 & 6,05 & 5,79 & 6,02 \\
\hline Ortalama & 6,84 & 6,33 & 7,4 & 6,12 & 6,17 & 6,18 & 5,94 & 6,11 \\
\hline
\end{tabular}

Kaynak: Trademap, 2019 verileri esas alınarak hesaplanmıştır.

Türkiye'nin RCA, RXA ve RTA endeks verileri göz önüne alındığında; söz konusu bu değerler 1'den büyük bulunmuştur. Bu değerler, Türkiye'nin uluslararası demir veya çelikten eşya ticaretinde rekabet avantajına sahip olduğunu göstermektedir. 2001-2018 dönemde her üç endeks değeri de genel olarak yüksek artış oranları ile yükselmiştir.

Analize konu olan söz konusu ülkelerin hem RC ve hem de RCA değerleri kıyaslandığında (bkz. Tablo-4 ve Tablo-8) RC değerlerinin RCA değerlerinden daha yüksek olduğu görülmektedir. RCA endeksi düşük olan Türkiye'nin RC endeks değeri yüksek bulunmuştur. Bu durum, karşılaştırmalı avantaja sahip olan Türkiye'nin aynı zamanda güçlü bir rekabet üstünlüğüne sahip olduğunu göstermektedir. Söz konusu diğer ülkelerle klyaslandığında rekabet gücünün yüksek olduğu görülmektedir. Türkiye'nin demir veya çelikten eşya sektörüne ait verilerinin ithalat verilerine göre daha iyi bir performans gösterdiği anlaşılmaktadır. Vollrath'ın RC endeksine göre Türkiye, ülkeler arası karşılaştırmada İtalya'dan sonra en güçlü rekabet üstünlüğüne sahip ülke konumundadır. Bu sonuçla Türkiye, 
RCA ve RXA endekslerinde yüksek avantaja sahip olan Polonya, Çek Cumhuriyeti ve Avusturya'yı geride bırakmıştır.

Rekabet gücü, bir ülkenin herhangi bir sektör veya bu sektördeki bir ürünün rekabet edebilecek üretim, uzmanlaşma, verimlilik esasına dayalı üstünlük noktasına ulaşması ve bu istikrarı koruyarak devam ettirebilmesini ifade eder. Bunu sağlayabilmek için düşük maliyetli ve istikrarlı üretimin yanı sıra üretilenin dünya ticaretine kazandırılabilmesi gerekir.

Tablo 4'te hesaplanan Balassa'nın açıklanmış karşılaştırmalı üstünlük (RCA) endeksi verileri esas alınarak değişim katsayısı hesaplanmış ve rekabet durumu değerlendirilmiştir. $\mathrm{Bu}$ verilere göre, Çek Cumhuriyeti, Polonya, Avusturya ve İtalya'nın orta düzeyde rekabet gücüne sahip olduğu; Türkiye, Almanya ve Fransa'nın zayıf rekabet gücüne sahip olduğu ve nihayet Hollanda'nın rekabet gücünün olmadığı sonucuna varılmaktadır. Değişim katsayı değerleri Almanya ve Fransa'nın daha istikrarlı olduklarını göstermektedir. Değişim katsayısı yüksek olan Türkiye'nin rekabet gücü bakımından istikrarsızlık düzeyine işaret etmektedir. Rekabet gücü değeri yüksek olan Polonya da istikrarsız bir duruma sahiptir. İtalya ve Çek Cumhuriyeti orta düzey istikrarlı bir seyir izlemektedir.

Tablo 9. Rekabet gücü karşılaştırması

\begin{tabular}{|l|c|c|l|}
\hline \multicolumn{1}{|c|}{ Ülkeler } & RCA Ortalaması & Değişim Katsayısı (\%) & \multicolumn{1}{c|}{ Rekabet Gücü } \\
\hline Türkiye & 1,43 & 0,33 & Rekabet Gücü Zayıf \\
\hline Almanya & 1,48 & 0,06 & Rekabet Gücü Zayıf \\
\hline İtalya & 2,47 & 0,12 & Rekabet Gücü Orta \\
\hline Fransa & 1,23 & 0,07 & Rekabet Gücü Zayıf \\
\hline Polonya & 3,03 & 0,21 & Rekabet Gücü Orta \\
\hline Çek Cum. & 3,84 & 0,12 & Rekabet Gücü Orta \\
\hline Avusturya & 2,5 & 0,18 & Rekabet Gücü Orta \\
\hline Hollanda & 0,77 & 0,1 & Rekabet Gücü Yoktur \\
\hline
\end{tabular}

Kaynak: Trademap, 2019 verileri esas alınarak hesaplanmıştır.

\section{SONUÇ}

Demir veya çelikten eşya endüstrisi için Türkiye'nin karşılaştırmalı üstünlük ve rekabet gücünün Balassa'nın açıklanmış karşılaştırmalı üstünlükler endeksi ve Vollrath'ın rekabet gücü endeksleri esas alınarak analiz edildiği bu çalışmada, Armonize Mal Tanımı ve Kodlama Sistemi (GTIP) 6 haneli ürün grupları temelinde elde edilen analiz sonuçlarına göre, Türkiye demir veya çelikten eşya sektöründe uluslararası ticaret piyasalarında karşılaştırmalı üstünlük 
ve rekabet gücüne sahiptir. AKÜ endeksine göre Türkiye, uluslararası ticarette rakibi olan Fransa ve Hollanda'ya karşı üstün olmasına karşın, İtalya, Polonya, Çek Cumhuriyeti ve Avusturya'ya karşı dezavantajlı, Almanya ile başa baş durumdadır. Rekabet üstünlüğü endeksine göre Türkiye, İtalya dışındaki rakiplerini geride bırakmıştır.

Yapılan analizlerden elde edilen sonuçlar arasında bir takım farklı değerler mevcuttur. Bunun nedeni olarak, Balassa'nın AKÜ endeksi ile Vollrath'ın rekabet gücü endeksleri arasında hesaplama yöntemine dahil olan içeriklerden kaynaklandığı gösterilebilir. Balassa'nın RCA endeksi ile Vollrath'ın RXA ve RTA değerleri birbiriyle örtüşmektedir. Bu endekslere göre, Türkiye 2003'ten günümüze (2007 istisna) kadar uluslararası ticarette avantajlı bir konumda bulunmaktadır. Türkiye, rekabet halinde olduğu ülkelerle kıyaslandığında bu rekabette geri kalmaktadır. Bu değerleri rekabet gücü bakımından değerlendirecek olursak, Türkiye rakiplerine karşı istikrarlı bir rekabet gücü sergileyememiştir. Türkiye, dünya ticaretinde karşılaştırmalı üstünlüğünü daha istikrarlı hale getirmelidir. Rekabet avantajını koruyabilmesi için, kaliteli, üstün nitelikli, kabul edilebilir maliyetli, yüksek verimli ürünlere ağırlık vermeli ve mevcut pazarlardaki konumunu güçlendirerek yeni pazarlara giriş sağlamalıdır. Vollrath'ın rekabet üstünlüğü (RC) endeksine göre ise Türkiye, rakiplerine karşı üstünlük kurmuş durumdadır.

Çalışmadan elde edilen bulgulara göre, Türkiye 2001-2018 döneminde (2007 hariç) karşılaştırmalı üstünlük ve rekabet gücünde pozitif yönlü bir yükselme eğiliminde olduğudur. 2003 yılından itibaren devletin yönlendirme ve katkılarıyla firmaların AR-GE çalışmalarına ağırlık vermeleri, teknolojik üretim modelini benimsemeleri ile birlikte ürettikleri ürünleri uluslararası piyasalara sunmaları neticesinde gerçekleşmiştir.

Türkiye'nin demir veya çelikten eşya endüstrisinin rekabet gücünü olumsuz etkileyen unsurlar olarak Uzak Doğu (Çin, Hindistan, Tayland, G. Kore) ülkelerinin düşük maliyetli üretimi ve denizyolu nakliye avantajının yanı sıra Avrupa ülkelerinin teknolojik üretim modeli neticesinde elde ettikleri kaliteli ürünler gösterilebilir. Bu durum, Türk işletmelerinin uluslararası ticaretine olumsuz etki etmektedir.

Türkiye coğrafi konumu gereği elinde bulundurduğu çevresel avantajını çok iyi değerlendirmelidir. Rekabet gücü avantajına sahip olamadığımız Uzak Doğu ülkelerine karşı zamanında ve hızlı teslim etme avantajı iyi değerlendirilmelidir. Kalite-maliyet ilişki düzeyinde geliştireceği dış ticaret stratejileri ve ülkeler arası ekonomik ilişkilerin üst düzeye çıkarılması ile mevcut ve yeni pazarların elde edilmesi gayet mümkün olacaktır. Orta Doğu ve Afrika pazarı 
için dengeli maliyet, Avrupa pazarı için ise kaliteli ürün ve hizmet çerçevesinde hareket edilmelidir.

\section{REFERENCES / KAYNAKLAR}

Altay, B. \& Gürpınar, K. (2008). Açıklanmış karşılaştırmalı üstünlükler ve bazı rekabet gücü endeksleri: Türk mobilya sektörü üzerine bir uygulama. Afyon Kocatepe Üniversitesi İktisadi ve İdari Bilimler Fakültesi Dergisi, 10(1), 257-274.

Aynagöz Çakmak, Ö. (2005). Açıklanmış karşılaştırmalı üstünlükler ve rekabet gücü: Türkiye tekstil ve hazır giyim endüstrisi üzerine bir uygulama. Ege Akademik Bakış Dergisi, 5(1), 65-70.

Bağcı, E. (2016). Türkiye'nin imalat sanayi sektörünün uluslararası rekabet gücü analizi. Marmara Üniversitesi Íktisadi ve İdari Bilimler Dergisi, 38(1), 73-92.

Balassa, B. (1965). Trade liberalization and revealed comparative advantage. Manchester School of Economic and Social Studies, 33.

Bashimov, G. (2017). Halı sektöründe karşılaştırmalı üstünlük: Türkiye, Çin ve Hindistan örneği. İktisadi Yenilik Dergisi, 4(3), 39-51.

Bashimov, G. (2018). Tacikistan'ın pamuk sektöründeki rekabet gücü. Yalova Sosyal Bilimler Dergisi, 8(16), 2036.

Çelik, Z., Saçtı, H. \& Adanacıoğlu, H. (2019). Kiraz dış ticaretindeki gelişmeler ve Türkiye'nin karşılaştırmalı üstünlüğü. Yüzüncü Yll Üniversitesi Tarım Bilimleri Dergisi, 29, Özel Sayı, 41-59.

Çeştepe, H. \& Tunçel, A. (2018). Türkiye demir çelik sektörünün uluslararası rekabet gücü analizi. Turkish Studies International Congress on Social Sciences II (INCSOS 2018 Quds), 13(15), 113-129.

Erkan, B. (2019). Ülkelerin ihracat performanslarının belirlenmesinde açıklanmış karşılaştırmalı üstünlüklerinin kullanılması: Yükselen ekonomiler örneği (Doktora tezi). Celal Bayar Üniversitesi, Manisa.

Laursen, K. (1998). Revealed comparative advantage and the alternatives as measures of international specialization. Danish Research Unit For Industrial Dynamics, DRUID Working Paper No:98-30.

Manavgat, G. \& Kaya, A. (2016). Türk imalat sanayinin uluslararas1 rekabet gücünün belirleyenleri: Panel veri analizi. Hacettepe Üniversitesi İktisadi ve İdari Bilimler Fakültesi Dergisi, 34(3), 1-22.

Özdamar, G. (2014). İmalat sanayisinde Türkiye'nin AB ile ticaretinin yapısı ve rekabet gücü: Teknoloji düzeylerine göre bir inceleme. Dumlupinar Üniversitesi Sosyal Bilimler Dergisi, 41, 11-30.

Sarıçoban, K., Kösekahyaoğlu, L. \& Erkan, B. (2017). Türkiye'nin imalat sanayi ürün gruplarındaki ihracat rekabet gücünün belirlenmesi: 1996-2015 dönemi analizi. Journal of Life Economics, 4(3), 49-72.

Şahin, D. (2016). İmalat sanayinde rekabet gücünün ölçümü: Türkiye ve BRIC ülkeleri örneği. Ege Akademik Bakış Dergisi, 16(4), 709-718.

Trade Statistics For International Business Development (Trade Map). Erişim Tarihi: 20.07.2019, https://www.trademap.org adresinden

Türkiye İhracatçılar Meclisi (TIM). İhracat 2019 raporu. Erişim Tarihi: 29.07.2019, http://www.tim.org.tr/files/downloads/sunumlar/Y\%C3\%B6nlendirme\%20Sunumlar\%C4\%B1/Karisik/Yeni\%20 Vizyon\%20Yeni\%20Yol\%20Haritas\%C4\%B1\%20\%C4\%B0hracat\%202019\%20Raporu.pdf 
Türkiye İstatistik Kurumu (TÜİK). Erişim Tarihi: 23.07.2019, https://biruni.tuik.gov.tr/disticaretapp/ disticaret.zul? param1 $=23 \&$ param2 $=4 \&$ sitcrev $=0 \&$ isicrev $=0 \&$ sayac $=5802$

Türkiye Kalkınma Bankası. (2006). Dış ticaretteki rekabet gücüne göre sanayi sektörünün değerlendirilmesi. Erişim Tarihi: 29.07.2019, http://www.kalkinma.com.tr/data/file/raporlar/ESA/ga/2007-GA/GA-06-0404_Dis_Ticaretteki_Rekabet_Gucune_Gore_Sanayi_Sektorunun_Degerlendirilmesi_1995_2005.pdf

Türkiye Odalar ve Borsalar Birliği (TOBB). Türkiye Mobilya Ürünleri Meclisi sektör raporu 2014. Erişim Tarihi: 24.07.2019, https://www.tobb.org.tr/Documents/yayinlar/2014/T\%C3\%9CRK\%C4\%B0YE\%20MOB\%C4\% B0LYA\%20\%C3\%9CR\%C3\%9CNLER\%C4\%B0\%20MECL\%C4\%B0S\%C4\%B0\%20SEKT\%C3\%96R\%20R APORU\%202014.pdf

Vollrath, T. L. (1991). A theoretical evaluation of alternative trade intensity measures of revealed comparative advantage. Weltwirtschafliches Archiv, 127, 265-279.

Yalçınkaya, M., Çılbant, C. \& Özçalık, M. (2009). Avrupa birliği sürecinde Türk imalat sanayi dış ticaretinin rekabet gücü: 1989-2009 dönemi var analizi. Yönetim ve Ekonomi: Celal Bayar Üniversitesi İktisadi ve İdari Bilimler Fakültesi Dergisi, 16(1), 115-137.

Y1ldırım, S. (2010). 2008 y1lı küresel ekonomi krizinin dünya ve Türkiye ekonomisine etkileri. KMÜ Sosyal ve Ekonomik Araştırmalar Dergisi, 12(18), 47-55. 